\title{
Matematik Öğretmeni Adaylarının Dijital Öyküleme Süreci ve Dijital Öykülerin Öğretim Ortamlarında Kullanımına Yönelik Görüşleri
}

İlknur ÖZPINAR, Yrd. Doç. Dr., Niğde Ömer Halisdemir Üniversitesi, Eğitim Fakültesi, ilknurozpinar@gmail.com, ORCID: http://orcid.org/ 0000-0002-3630-0991

Öz: Çalışmanın amacı öğretmen adaylarının, dijital öykülemeyi öğrendikleri, dijital öyküler oluşturdukları, öykülerin gerçek sınıf ortamında uygulamalarını gözlemledikleri ve uygulamaların etkililiklerini tartıştıkları bir hizmet-öncesi eğitim süresince, süreç üzerine düşüncelerini incelemektir. Özel durum çalışması kapsamında gerçekleştirilen çalışmanın katılımcılarını bir devlet üniversitesinin Eğitim Fakültesi matematik öğretmenliği programı üçüncü sınıfında öğrenim görmekte olan 54 öğretmen adayı oluşturmaktadır. Araştırmanın verileri yazılı görüş formları aracılığıyla toplanmıştır. Çalışmanın sonunda öğretmen adaylarının dijital öyküleri hazırlarken teknik sorunlarla karşılaştıkları ve öykü oluşturma sürecinde zorlandıkları ortaya çıkmıştır. Ayrıca öğretmen adaylarının büyük çoğunluğu dijital öykülemenin öğretim sürecinde kullanılmasının; aktif katılım, başarı, motivasyon ve yaratıcılık gibi pek çok açıdan eğitsel avantajının olduğunu belirtmiş ve uygulamaya ilişkin olumlu görüş bildirmişlerdir.

Anahtar Kelimeler: dijital öyküleme, teknoloji entegrasyonu, öğretmen adayı, matematik öğretimi.

\section{Preservice Mathematics Teachers' Opinions on the Use of Digital Stories and Instructional Environments}

Abstract: The purpose of this study is to examine preservice teachers' opinions on the process of preservice education with components through which they learn digital storytelling, develop digital storytelling activities and observe how teachers implement the activities they develop and discuss the effectiveness of those activities. Having been carried out with the case study method, participants of the study were 54 preservice teachers who are attending the third year of the mathematics education department in the Faculty of Education at a state university. The data of the research were collected with written interview forms. At the end of the study, it was revealed that the preservice teachers had technical problems when preparing the digital stories and had experienced difficulties in the process of creating a scenario. Moreover, majority of the preservice teachers stated that using the digital storytelling in instructional processes has many educational advantages such as active participation, achievement, motivation and creativity and reported positive opinions on the application.

Key Words: digital storytelling, technological integration, preservice teachers, mathematics education. 


\section{GíRiş}

Hızla gelişmekte ve değişmekte olan teknoloji, yaşamın her alanında kullanılmakta olup günümüz insanlarının vazgeçilmez bir ihtiyacı haline gelmiştir. Bireylerin teknolojiyi anlayabilmesi, uyum sağlayabilmesi ve ortaya koyduğu fırsatlardan yararlanabilmesi için bilgi, beceri ve alışkanlık kazanmaları gerektiğinden; her alanda olduğu gibi eğitim alanında da değişim ve gelişim kaçınılmaz olmuştur (Baki, Yalçınkaya, Özpınar ve Çalık Uzun, 2009; Karataş, Bozkurt ve Hava, 2016; Oral, 2004). Günlük hayatta yeni teknolojileri kullanmanın gerekliliği ile birlikte eğitimde etkili öğrenmeyi sağlayan yeni yöntemler ortaya çıkmış olup, bu yöntemlerden biri de dijital öykülemedir (Duman ve Göcen, 2015).

Öyküleme geçmişten günümüze karmaşık, zor ve soyut konuları açıklamak için kullanılan basit ama güçlü ve etkili bir araçtır (Duman ve Göcen, 2015; İnan, 2015; Robin, 2006, 2008; Sadik, 2008; Smeda, Dakich ve Sharda, 2014; Van Gils, 2005). Günümüzde bilgi ve iletişim teknolojilerinin hızlı gelişimi ve gittikçe artan popülaritesi ile birlikte geleneksel öykülemenin yerini, dijital öyküleme almıştır (Condy, Chigona, Gachago ve Ivala, 2012).

Son zamanlarda dijital öyküleme, dijital dünyayı eğitimle ilişkilendirmek için okul öncesinden başlayarak yetişkin eğitimine kadar kullanılan önemli bir araç haline gelmiştir (Duman ve Göcen, 2015; Incikabi, 2015). Alanyazında dijital öyküleme ile ilgili birçok farklı tanım bulunmaktadır. Genel olarak, belirli bir konuyla ilgili bilgi vermek amacıyla video, grafik, metin, ses ve müzik gibi çoklu ortam öğelerinin öyküleme yoluyla bir araya getirilmesi çerçevesinde ele alındığı görülmektedir (Jakes ve Brennan, 2005; Robin, 2006). Robin'e (2008) göre dijital öyküleme özünde; öğrencilerin bir konuyu seçmesi, bazı araştırmalar yapması, öykü yazması ve ilginç bir öykü oluşturması gibi geleneksel süreçleri kullanarak yaratıcı öykü anlatıcıları olmalarını sağlamaktadır. Dijital öykülemede izleyicilerin sadece dinleyici olarak değil, aynı zamanda süreçte öyküyü etkinleştirebilen ve şekillendirebilen öğreniciler olarak yer alması, onu geleneksel öykülemeden farklılaştırmaktadır (Sadik, 2008; Woodhouse, 2008). Dijital öykülerin; kişisel öykü anlatımı, tarihsel olayların anlatımı ya da belirli bir konuyla ilgili bilgi verme veya öğretme için kullanılan bir araç olma gibi çeşitli kullanım alanları bulunmaktadır (Dogan ve Robin, 2008; Robin, 2008).

Başarılı bir dijital öykü geliştirmek için dijital öykülemenin aşamalarını eksiksiz olarak tamamlamak gerekmektedir (Karakoyun, 2014). Jakes ve Brennan (2005) dijital öykü oluşturma sürecinin adımlarını; yazma, senaryo oluşturma, öykü panosu oluşturma, çoklu ortam öğelerini araştırma, dijital öykü oluşturma ve paylaşma olarak incelemiştir. Dijital öyküler ile çalışılırken öykü geliştirme sürecinde Dijital Öykü Anlatımı Merkezi, dijital öykülemenin yedi bileşeninin dikkate alınmasını önermektedir: Öykünün temel amacını ve yazarın bakış açısını yansıttığı bakış açısı; öykünün sonuna kadar izleyicilerin dikkatini çekecek çarpıcı soru; öykünün izleyici ile kişisel ve güçlü bir şekilde etkileşim kurmasını sağlayan nitelikte olan duygusal içerik; öyküyü oluşturanların öykünün daha iyi anlaşılması için seslendirme yoluyla canlandırma yaptığı ses kullanımı; öyküyü desteklemek için uygun ses ve müziklerin kullanıldığı sesin gücü; öykünün sade bir şekilde, gereğinden fazla içerik sunulmadan görsel ve seslerin ekonomik olarak kullanıldığı ekonomi ile öykünün ne kadar yavaş ya da hızı ilerleyeceğinin belirlendiği hız denetimi (Robin, 2008).

Dijital öyküleme günümüz eğitim dünyasında önemli bir role sahip olup (Karakoyun, 2014); öğretim ortamında öğrencilere içeriği öğretme, aktif araştırmalar yaptırma, yazmayı öğretme gibi çeşitli amaçlarla kullanılabilir (Dogan ve Robin, 2008). Öğrencilerin etkin olarak dijital öykü oluşturma sürecine katılmasıyla; yaratıcı düşünme becerileri, hayal güçleri, araştırma becerileri ve teknolojik yeterlikleri gelişmekte olup; motivasyonları ile akademik başarıları da artmaktadır (Duman ve Göcen, 2015; Duveskog, Tedre, Sedano ve Sutinen, 2012; 
Hung, Hwang ve Huang, 2012; Jakes ve Brennan, 2005; Karataş, Bozkurt ve Hava, 2016; Kocaman-Karaoğlu, 2015; Ohler, 2006; Robin, 2006; Yang ve Wu, 2012). Van Gils (2005) de eğitimde dijital öykülerin kullanımının öğretime çeşitlilik kattığı, eğitimin kişiselleştirilebilmesine fırsat verdiği, ilgi çekici olduğu, gerçek yaşam durumları ile ilişkilendirilebildiği, merak uyandırıcı olduğu ve aktif öğrenme için etkili bir yol olduğu üzerinde durmuştur.

Eğitim alanında değişimin ve gelişimin gerçekleşmesi için gerekli olan faktörlerin en önemlilerinden biri de, eğitim sistemine yenilik getirmekte önemli rol üstlenmekte olan öğretmenlerdir. Öğretmenlerin eğitim kurumlarında değişimi gerçekleştirebilmesi için her şeyden önce kendilerinin değişimi kabul etmeleri, özellikle teknoloji alanında meydana gelen gelişmelerden haberdar olmaları (Baki, 2000; Baki, Yalçınkaya, Özpınar ve Çalık Uzun, 2009; Hardy, 1998; Oral, 2004) ve bilgiye ulaşıp kullanan bireyler yetiştirebilmek için teknolojik araç gereçleri etkili bir biçimde kullanabilmeleri gerekmektedir (Çakır ve Yıldırım, 2009). Son yıllarda yapılan matematik ve diğer alanlardaki araştırmaların birçoğu teknolojinin öğrenmeye ve başarıya olan olumlu katkısını ortaya koymaktadır. Matematiksel içeriğin daha iyi anlaşılması için teknolojinin etkili ve doğru kullanılması gerektiğinden, bu durum Matematik Öğretmeni Özel Alan Yeterlikleri kapsamında da ele alınmaktadır. Matematik Öğretmeni Özel Alan Yeterlikleri, 'Matematik Öğretim Durumlarını Planlama ve Düzenleme' yeterlik alanı kapsamında 'Matematik Öğretiminde Teknolojik Kaynakları Kullanabilme' yeterliği incelendiğinde de öğrenmenin daha etkin gerçekleşebilmesi için yazılımlardan yararlanma, teknolojik kaynakları değerlendirerek sistematik olarak kullanma, mevcut olanakları göz önünde bulundurularak öğrencilerin teknolojik kaynaklardan faydalanabilmeleri için uygun ortam hazırlama ve matematik öğreniminde ihtiyaç duyulan teknolojik kaynakları çeşitlendirme gibi göstergelerin bulunduğu görülmektedir (Milli Eğitim Bakanlığı [MEB], 2008).

Öğretmenlerin rollerini nitelikli bir şekilde gerçekleştirebilmeleri için öncelikle alanlarında iyi eğitim almış olmaları gerekmektedir. Bu da üniversite eğitimi sırasında etkili ve yeterli düzeyde alan ve eğitim derslerini almış olmaları, uygulama olanaklarından yeterince yararlanmaları, derslerde gerekli öğretim teknolojileri ve materyalleri kullanmaları ile mümkün olabilmektedir (Büyükgöze Kavas ve Bugay, 2009). Ancak alanyazında öğretmen adaylarının teknoloji entegrasyonu ile ilgili yeterli bilgi ve beceriye sahip olmadan mezun oldukları belirtilmektedir (Ledermen ve Neiss, 2000). Oysaki eğitimin kalitesini artırmak için öğretmenlerin daha nitelikli yetiştirilmesi, bunun için de öğretmen niteliğini yükseltmeyi sağlayan önemli unsurların başında gelen hizmet-öncesi öğretmen yetiştirme çalışmalarına daha fazla önem verilmesi gerekmektedir (Büyükgöze Kavas ve Bugay, 2009). Niess ve Garofalo (2006) matematik öğretmenlerinin konuları öğrendikleri şekilde öğretmeyi tercih ettiklerini, bunun için de teknoloji kullanılarak anlatılan derslerin öğretmen adaylarının deneyimlemeleri gerektiğini belirtmiştir (Akt., Demir ve Bozkurt, 2011). Bu durumda hangi teknolojinin nasıl kullanılacağı konusunda doğru kararlar alabilmeleri için öğretmen adaylarına ilgili bilgi ve beceriler edindirilerek; teknoloji çeşitliliği ve teknolojinin kullanımını etkileyen deneyimler sağlandıktan sonra teknolojiyi entegre etmeleri istenmelidir (Demir ve Bozkurt, 2011; Mistretta, 2005).

Teknolojinin eğitime girişiyle birlikte öğrenme ortamlarında yeni yöntem ve tekniklerin kullanılması da olanaklı hale gelmiştir (Öksüz, Ak ve Uça, 2009). Öğretmenlerin öğretimlerinde kullandıkları yöntem ve teknikler etkili teknoloji kullanımlarını şekillendirmektedir (Çakır ve Yıldırım, 2009). Öğrencilerin çoklu ortam sunumları yapmaları, proje için veri toplama ve yorumlamaları yüksek seviyede teknoloji entegrasyonunun göstergesidir (Cuban, Kirkpatrick ve Peck, 2001). Bu kapsamda dijital öykülemenin özellikle yüksek seviyede teknoloji entegrasyonu açısından matematik öğretiminde etkili bir öğrenme aracı olarak kullanılabileceği 
düşünülmektedir. Öyküleme, öğrencilerin hayal güçlerine ve duygularına hitap ederek, öğrenmelerini daha anlamlı kılmalarına yardımcı olmaktadır (Goral ve Gnadinger, 2006). Ayrıca son yıllarda matematik eğitiminde öyküler, hem bilginin yaygınlaştırılması hem de matematiğin anlaşılması açısından ilgi görmeye başlamıştır (Schiro ve Lawson, 2004). Matematik eğitiminde öyküler; öğrencilerin sınıfta öğrendikleri ve yaşamları ile ilişkilendiremedikleri gerçekleri, algoritmaları ve prosedürleri anlamalarını sağlamada yardımcı olabilecek güçlü bir bilişsel araçtır (Balakrishnan, 2008). Alanyazında matematik öğretiminde dijital öykülemeye yönelik araştırmaların sınırlı sayıda ve çoğunlukla okulöncesi eğitiminde olmakla birlikte (Casey 2004; Casey, Kersh ve Young 2004; Casey, Erkut, Ceder ve Young, 2008), ilkokul, ortaokul ve lise (Albano ve Pierri, 2014; Goral ve Gnadinger, 2006; Incikabi, 2015), öğretmen ve öğretmen adayları (Gordon, 2011; Incikabi ve Kildan, 2013; İnan, 2015; Kildan ve Incikabi, 2015; Sancar Tokmak ve Incikabi, 2013; Starčič, Cotic, Solomonides ve Volk, 2016) ile yapılan uygulamalarının da bulunduğu görülmektedir. Ancak alanyazın incelendiğinde bu konuda yeteri kadar çalışma yapılmadığı, ülkemizde de özellikle matematik öğretmen adayları ile gerçekleştirilen çalışmalara intiyaç duyulduğu açıktır. Matematik gibi soyut kavramların bulunduğu bir derste öğrencileri de öğrenme sürecine dâhil ederek ilgili kavramların açıklanmasını kolaylaştıran dijital öykülemelere (Albano ve Pierri, 2014) matematik derslerinde daha fazla yer verilmesi gerekmekte ve dolayısıyla da öğretmen yetiştiren kurumlardan, dijital öyküler üretebilen ve eğitim ortamlarına entegre edebilen öğretmenler hazırlamaları beklenmektedir (Incikabi, 2015, s. 165). Ilgili tespitlerden hareketle bu çalışmanın amacı öğretmen adaylarının; dijital öykülemeyi öğrendikleri, dijital öyküler oluşturdukları, öykülerin gerçek sınıf ortamında uygulamalarını gözlemledikleri ve uygulamaların etkililiklerini tartıştıkları bir hizmet-öncesi eğitim süresince, süreç üzerine düşüncelerini incelemektir.

\section{YÖNTEM}

İlgili araştırma, öğretmen adaylarının dijital öyküleme üzerine verilen hizmet-öncesi eğitim süreci hakkındaki görüşlerini belirlemeye yönelik, nitel bir çalışmadır (Miles ve Huberman, 1994, s. 9). Çalışmada incelenen durumu detaylı olarak tanımlamak, açıklamak, değerlendirmek ve olaylar arasındaki olası ilişkileri ortaya çıkarmak amaçlandığından özel durum çalışması yöntemi kullanılmıştır (Patton, 2002; s. 447; Yin, 1994, s. 13).

\section{1. Çalışma Grubu}

Çalışma grubunu, bir devlet üniversitesinin Eğitim Fakültesi matematik öğretmenliği programı üçüncü sınıfına devam eden 42'si kadın ve 12'si erkek olmak üzere toplam 54 öğretmen adayı oluşturmaktadır. Araştırmada amaçlı örnekleme yöntemlerinden ölçüt örnekleme kullanılmıştır. Öğretmen adaylarının birinci sınıfta Bilgisayar I ve II, ikinci sınıfta ise Eğitim Teknolojileri Uygulamaları (Seçmeli) ve Öğretim Teknolojileri ve Materyal Tasarımı derslerini almış olmaları; uygulamada kullanılacak olan yazılımlar konusunda bilgi sahibi olup, uygulamalar gerçekleştirmiş olmaları ile geçmişte öykülemeyle ilgili bilgi ve deneyimlerinin bulunmaması çalışmada temel ölçütler olarak belirlenmiştir.

\subsection{Uygulama Süreci ve Veri Toplama Araçları}

Bu çalışma öğretmen adaylarının dijital öyküleme üzerine aldıkları hizmet-öncesi eğitim sürecini içermektedir. Özel Öğretim Yöntemleri I dersi kapsamında yürütülen araştırmada, dijital öykülerin hazırlanma süreci başlamadan önce ilk iki hafta öğretmen adaylarına dijital öyküleme hakkında bilgi verilmiş, örnekler gösterilmiş, tartışmalar yürütülmüş ve soruları yanıtlanmıştır. Dijital öyküler oluşturulurken öğretmen adayları MovieMaker ve GoAnimate ile süreç içinde birlikte çalışmalarını destekleyen çeşitli internet sayfalarından faydalanmışlardır. Öğretmen adaylarının kullanacakları yazılımları kullanabilme becerilerini geliştirebilmeleri için bir bilgisayar ve öğretim teknolojileri eğitimi uzmanı tarafından yine ilk iki hafta süresince 
MovieMaker yazılımının nasıl kullanıldığı ve GoAnimate ortamında animasyonun nasıl hazırlanacağı tanıtılmıştır. Ardından öğrenci görüşleri ve heterojen yapıda olmaları dikkate alınarak on tane 5'er kişilik ve bir tane de 4 kişilik olmak üzere on bir grup oluşturulmuştur. Gruplar oluşturulduktan sonra grup olarak öğrencilerden ilk dijital öykülerini hazırlamaları istenmiştir.

Öğretmen adayları dijital öykülerini oluştururken Dijital Öykü Merkezinin dikkate alınmasını önerdiği bakış açısı, çarpıcı soru, duygusal içerik, sesin kullanımı, müziğin gücü, ekonomi ve hız denetiminden oluşan yedi bileşeni göz önünde bulundurmuşlardır. Dijital öyküleme sürecinde takip edilecek adımlar ise alanyazın incelenerek (Barrett, 2009; Jakes ve Brennan, 2005; Robin, 2014, s. 436) belirlenmiş olup Şekil 1'de verilmiştir.

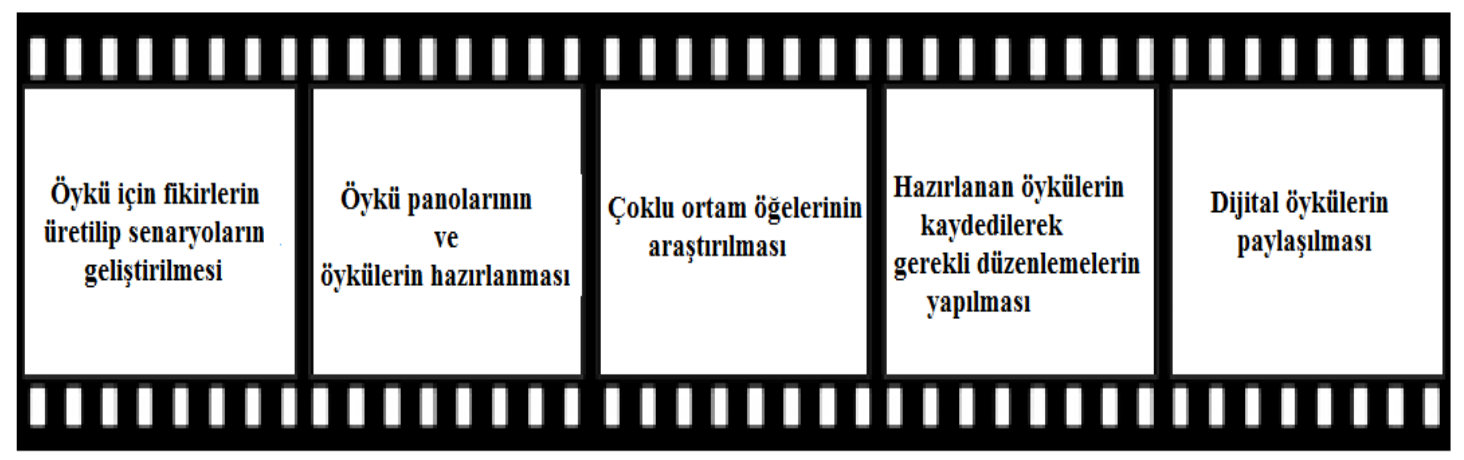

Şekil 1. Dijital öyküleme süreci

Robin (2006) tüm yeni öğretim yöntemlerinde olduğu gibi, öğrencilerin öykülemeyi kullanmaya başladıklarında onlardan ne beklendiğini öğrenmeleri için zamana ihtiyaçları olacağını; bu aşamada öğrencilerin ve öğretmenlerin birlikte öğrenci çalışmalarını ve süreci takip ederek, akranları ile tartışıp değerlendirebilecekleri ortamların sağlanması gerektiğini belirtmiştir. Bu amaçla öğretmen adaylarından grup olarak gerçekleştirdikleri haftalık etkinlikleri sunmaları istenmiştir. Hazırlanan etkinliklerin her hafta ilgili derste gruplar tarafından sınıfta sunumları gerçekleştirilmiş, büyük grup tartışmaları ve iki uzmanın değerlendirmesi ile verilen dönütler doğrultusunda gerekli düzenlemeler yapılarak ilk dijital öyküler dört haftada geliştirilmiştir. Bu sürecin sonrasında gruplar geliştirecek oldukları dijital öykülerini sınıf ortamında uygulamak için bir devlet ortaokulunda görev yapmakta olan gönüllü üç matematik öğretmeni ile görüşmüş; dijital öykülerin hazırlanmasına yönelik olarak, öğretmenlerin uygulamayı yapacakları sınıflarının seviyesi ve hangi kazanımların ele alınacağı belirlenmiştir. Bu süreçte öğretmenlere dijital öyküleme konusunda bilgi verilmiş, ayrıca öğretmenlerin dört ders saati de gözlemlenmiştir. Matematik öğretmenleri ile gerçekleştirilen görüşmeler esnasında 8. sınıf matematik dersi öğretim programında (MEB, 2013) yer alan "Üçgenler, Dönüşüm Geometrisi ve Basit Olayların Olma Olasılığı" alt öğrenme alanlarına yönelik dijital öykülerin geliştirilmesine karar verilmiştir. Bu alt öğrenme alanlarının seçilmesinin sebebi ilgili kazanımlara yönelik gerçekleştirilebilecek uygulamaların öyküleme için uygun nitelikte olabileceğinin düşünülmesi ve matematik öğretmenlerinin bu konuların öğretimini ilgili sıra ile yapacaklarını belirtmiş olmalarıdır. Ayrıca, 8. sınıf öğrencilerinin Temel Eğitimden Ortaöğretime Geçiş (TEOG) sınavına hazırlandıklarından dolayı eğlenerek öğrenmelerini ve tekrar etmelerini sağlayarak motivasyonlarını yükselteceği düşüncesi ile bu sınıf seviyesi seçilmiştir. Görüşmelerin ardından gruplar taslak öykülerini hazırlamışlardır. ilgili aşamada öğretmen adaylarından yeni dijital öyküleri için grup olarak gerçekleştirdikleri haftalık etkinlikleri diğer gruplara sunmaları istenmiştir. Yapılan her sunumun ardından büyük grup tartışmaları ve iki uzmanın değerlendirmeleri sonucu verilen dönütler dikkate alınarak gerekli düzenlemeler yapılmıştır. Matematik öğretmenleri tarafından öğretim ortamlarında 
kullanılacak olan dijital öykülerin oluşturulma süreci beş hafta sürmüştür. Hazırlanan dijital öyküler derslerin farklı süreçlerinde dört hafta boyunca uygulanmıştır. Bu uygulamalar öğretmen adayları tarafından gözlenmiş, ardından uygulama esnasında karşılaşılan zorluklar ve bunların nasıl aşılabileceği tartışıımıştır. Sonrasında hazırlanan dijital öyküler tekrar gözden geçirilerek revize edilmiştir. Öğretmen adaylarının geliştirdikleri dijital öykülere ilişkin örnek ekran görüntüleri Şekil 2'de yer almaktadır.

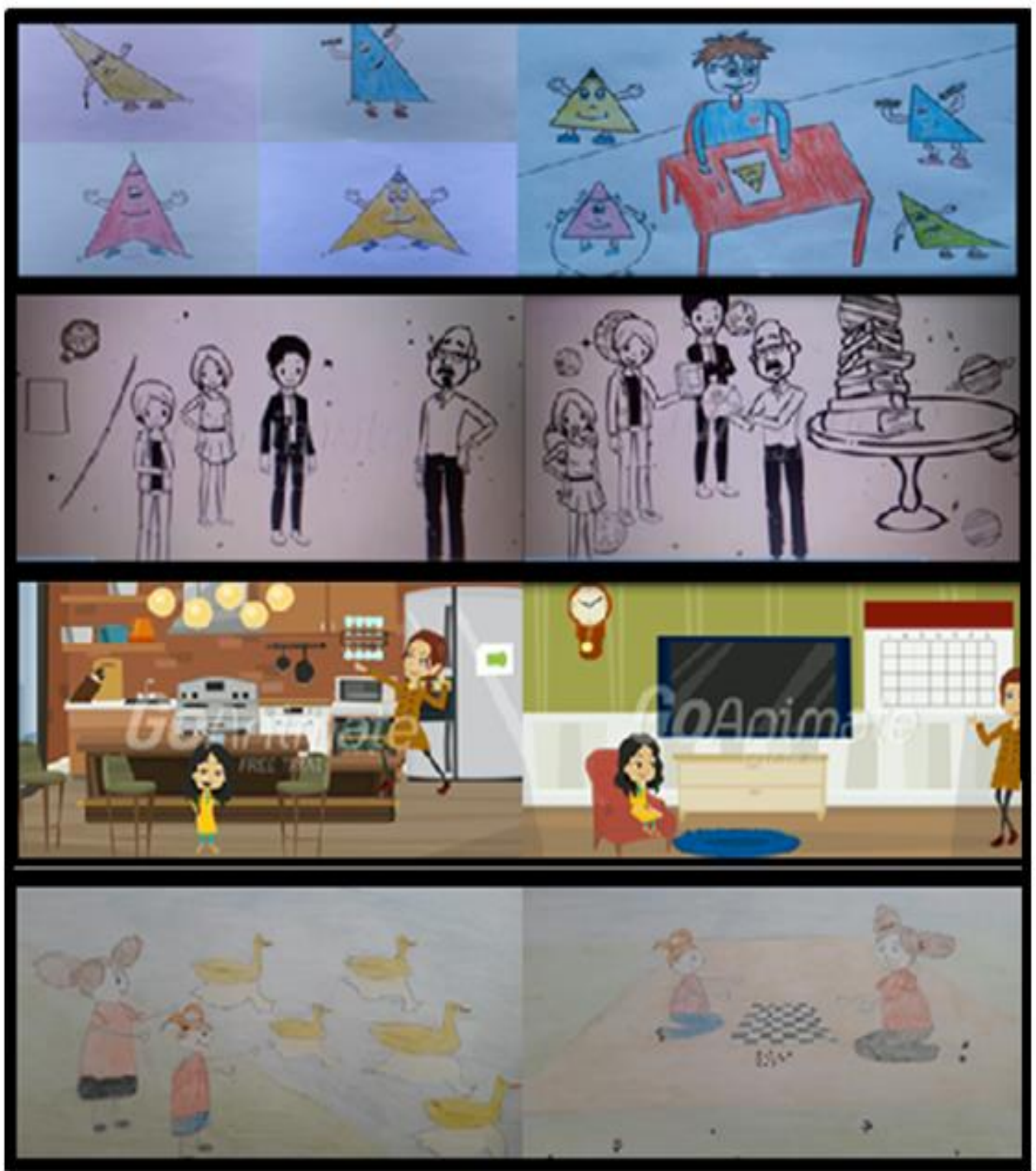

Şekil 2. Öğretmen adayları tarafından oluşturulan dijital öykülerin örnek ekran görüntüleri

Verilen hizmet-öncesi eğitimin ardından öğretmen adaylarının görüşlerinin alınması amacıyla; araştırmacılar tarafından geliştirilen, iki uzman görüşü ile son şekli verilen ve beş açık uçlu sorudan oluşan yazılı görüş formu kullanılmıştır. Görüş formunda yer alan sorular şu şekildedir: i) Dijital öykülerinizi hazırlarken nelere dikkat ettiniz? ii) Dijital öyküleme sürecinde karşılaştığınız problemler nelerdir ve bu problemlerin üstesinden nasıl geldiniz? iii) Dijital 
öykülemenin matematik öğretiminde kullanımına yönelik düşünceleriniz nelerdir? iv) Göreve başladığınızda matematik derslerinizde dijital öykülemeyi kullanmayı tercih eder misiniz? Neden? v) Dijital öyküleme üzerine almış olduğunuz eğitim sürecini değerlendiriniz.

\subsection{Veri Analizi}

Bu araştırmada yazılı görüş formlarından elde edilen verilerin analizi için içerik analizi kullanılmıştır. İçerik analizinde temel amaç toplanan verilerin açıklanmasını sağlayan kavramlara ve ilişkilere ulaşmaktır. İçerik analizi yoluyla veriler tanımlanmaya, verilerin içinde saklı olabilecek gerçekler ortaya çıkarılmaya çalışıı (Yıldırım ve Şimşek, 2006, s. 227). Çalışmada verilerin analizinden önce araştırma soruları kapsamında genel bir kavramsal yapı oluşturularak genel temalar belirlenmiş, kodlama yapılarak kendi içinde tutarlı ve bütünlük içinde olan bölümler tespit edilmiştir (Yıldırım ve Şimşek, 2006, s. 232). Araştırmanın yazılı görüş formlarından elde edilen kodlamaları temalar ile birlikte iki alan uzmanı tarafından incelenmiş, görüş ayrılığı olan konular tartışılarak gerekli düzenlemeler yapılmış ve kodlama güvenilirliği uyum yüzdesi indeksi \%86 olarak bulunmuştur. Elde edilen değer \%70'in üzerinde olduğundan ilgili araştırma için kabul edilmiştir (Miles ve Huberman, 1994, s. 64). Verilerin analizi sırasında katılımcıları birbirinden ayırt edebilmek amacıyla öğretmen adayları ÖA1, ÖA2, ÖA3,... şeklinde kodlanmıştır.

\section{BULGULAR}

Öğretmen adaylarının dijital öyküleri oluşturma ve uygulama sürecine yönelik düşünceleri alınmış ve elde edilen verilerin analizleri doğrultusunda aşağıdaki bulgulara ulaşılmıştır.

\section{1.Öğretmen Adaylarının Dijital Öyküleri Hazırlama Sürecinde Dikkate Aldıkları Hususlara İlişkin Görüşleri}

Katılımcılardan öncelikle oluşturdukları dijital öyküleri hazırlarken göz önünde bulundurdukları hususlara ilişkin görüşleri istenmiştir. Öğretmen adaylarııın ilgili konu hakkındaki görüşlerine ilişkin verilerin analizi sonucu elde edilen kodlar Tablo 1'de sunulmuştur.

Tablo 1

Dijital Öyküleme Sürecinde Dikkat Edilen Hususlara ilişkin Kodlar

\begin{tabular}{|c|c|c|}
\hline Tema & Kodlar & $f^{*}$ \\
\hline \multirow{7}{*}{ 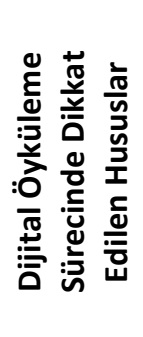 } & Matematik dersi öğretim programının incelenmesi & 41 \\
\hline & Öğretim üyelerinden görüş alınması & 38 \\
\hline & Öğrenci seviyesini göz önünde bulundurulması & 27 \\
\hline & Eğlenerek öğrenmeye katkı sağlaması & 23 \\
\hline & Matematik öğretmenleri ile görüşmelerin yapılması & 22 \\
\hline & Günlük yaşamla ilişkilendirmeye önem verilmesi & 17 \\
\hline & Öğrenciler ile görüşmelerin yapılması & 2 \\
\hline
\end{tabular}

* : Bazı öğretmen adaylarının cevapları birden fazla kod altında yerleştirildiği için toplam frekans değeri 54'ü aşabilir.

Katılımcıların çoğu dijital öyküleme sürecinde matematik dersi öğretim programını detaylı olarak incelediklerini, öğretim üyelerinden görüş aldıklarını ve öğrenci seviyesini göz önünde bulundurduklarını ifade ederken; bazıları da eğlenerek öğrenmeye katkı sağlamasını amaçladıklarını, matematik öğretmenleri ile görüşmeler yaptıklarını ve günlük yaşamla 
ilişkilendirmeye dikkat ettiklerini belirtmişlerdir. Konu ile ilgili ÖA17 ve ÖA52 öğretmen adaylarının görüşleri şu şekildedir:

"[...] Grup üyeleri ile bir araya geldik. Kazanımımızın günlük hayatla ilişkisini ortaya koyan videolar, forumlar vb. inceledik. Matematik öğretim programı çerçevesinde belirtilen yönergelerden yararlanarak yaş düzeyine uygun olarak dijital öykümüzü oluşturduk." (ÖA 17)

"[...] Kazanımımızdan yola çıkarak öğrencilerin yapması gereken çıkarımları tespit ettik. Bu doğrultuda konuların kalııılığını artırmak için günlük hayattan örnekler bulmaya yani hayatın içinden karşılaşacakları durumlardan hareket etmeye çalısstık ve öykülerimize ekledik. Örneğin; yansıma, dönme vb." (ÖA 52)

Diğer öğretmen adaylarından farklı olarak aynı grupta bulunan iki öğretmen adayı (ÖA32 ve ÖA33) öğrencilerle de görüşmeler gerçekleştirdiklerinden söz etmişlerdir. Bu konu hakkındaki ÖA33 öğretmen adayının görüşü aşağıda yer almaktadır:

"ilk dijital öykülerimizi matematik öğretim programını inceleyerek grup içinde tartısarak kararlaştırdık. [...] ikincisi olan öğrencilere uygulananı ise matematik öğretmenleri ve grup arkadaşlarım ile görüşerek belirledik. [...] Kazanıma uyan, eğlenceli, öğretici, öğrencilerin sıkılmadan zevk alarak izleyecekleri bir senaryoyu değişik okullardaki öğrencilere de danışarak oluşturduk. Bunu da Karagöz ve Hacivat oyunu olarak kararlaştırdık [...]" (ÖA 33)

3.2. Öğretmen Adaylarının Dijital Öyküleme Sürecinde Karşılaştıkları Problemler ve Çözümlerine ilişkin Görüşleri

Öğretmen adaylarının dijital öykülerini oluştururken karşılaştıkları problemler ve bu problemleri nasıl çözdüklerine ilişkin verilerin analizi sonucu Tablo 2'de belirlenen üç temaya ulaşılmış ve bunlara ilişkin kodlar aşağıda sunulmuştur.

Tablo 2

Dijital Öyküleme Sürecinde Karşılaşılan Problemler ve Problemlerin Çözümlerine Illişkin Tema ve Kodlar

\begin{tabular}{|c|c|c|c|c|}
\hline Temalar & Karşılaşılan Problemlere İlişkin Kodlar & $f^{*}$ & $\begin{array}{c}\text { Problemlerin Çözümlerine İlişkin } \\
\text { Kodlar }\end{array}$ & $f^{*}$ \\
\hline \multirow{6}{*}{ 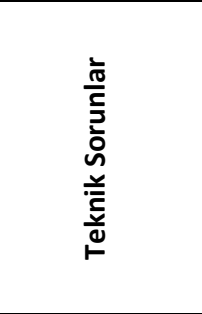 } & $\begin{array}{l}\text { MovieMaker yazılımı ve GoAnimate } \\
\text { ortamında animasyon hazırlama }\end{array}$ & 31 & Öğretim üyelerinden yardım alma & 31 \\
\hline & Ses kaydının netliği & 17 & Deneyerek üstesinden gelme & 8 \\
\hline & Ses hızının öykü akışı ile uyumu & 9 & & \\
\hline & Ses seviyesinin az ya da çok olması & 7 & & \\
\hline & Arka plan için uygun müzik seçimi & 3 & & \\
\hline & Video çekimi & 1 & & \\
\hline \multirow{6}{*}{ 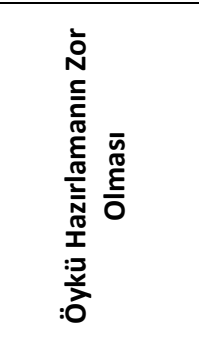 } & Öyküyü kurgulama & 15 & $\begin{array}{l}\text { Öğretim üyeleri ve akranlardan görüş } \\
\text { alma }\end{array}$ & 21 \\
\hline & Soyut kavramları somutlaştırmaya çalışma & 13 & Matematik öğretmenleri ile görüşme & 11 \\
\hline & Çizgi resim yapma & 11 & Öğrenciler ile görüşme & 7 \\
\hline & Seviyeye uygun yazma & 4 & & \\
\hline & Öykü karakterlerine karar verme & 3 & & \\
\hline & Gereğinden fazla bilgi verme & 1 & & \\
\hline \multirow{4}{*}{ 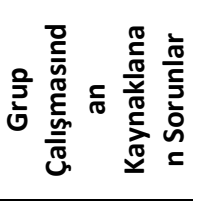 } & Birlikte çalışma & 7 & Bireysel çalışma & 7 \\
\hline & $\begin{array}{l}\text { İşbölümündeki görev ve sorumlulukların } \\
\text { yerine getirilmemesi }\end{array}$ & 5 & & \\
\hline & Grup üyelerine bağımlı olma & 3 & & \\
\hline & Eşit olmayan iş yükleri & 1 & & \\
\hline
\end{tabular}


* : Bazı öğretmen adaylarının cevapları birden fazla kod altında yerleştirildiği için toplam frekans değeri $54^{\prime}$ ü aşabilir.

Tablo 2 incelendiğinde öğretmen adaylarının dijital öykülerini geliştirirken karşılaştıkları problemlerin başında süreçte yaşanılan teknik sorunların ve öykü hazırlamanın zorluğunun geldiği görülmektedir. Farklı gruplarda bulunan öğretmen adayları karşılaştıkları teknik problemleri ve bu problemlerin üstesinden nasıl geldiklerini şu şekilde açıklamışlardır:

"Bilgisayar ve programdan kaynaklanan sıkıntılar yaşadık. Programdan kaynaklanan sıkıntıları programları tanıtan öğretim elemanına danışarak aştık. Sonrasında uygulama için hazırladığımız dijital öykülerde ise artık alıştığımızdan bu konuda sıkıntı yaşamadık. [...]" (ÖA 13)

"MovieMaker programını dijital öyküler için ilk defa kullanırken zorluk çektik. Deneme-yanılma yoluyla üstesinden geldik. [...] Kaliteli, net ve hışırtısız ses elde etmek için defalarca deneme yaptığımız oldu." (ÖA 42)

"Videoları hazırlarken teknik anlamda bazı zorluklarla karşılaştık. Örneğin, ses kayıtlarını videoya uygun bir şekilde düzenlerken bazı sorunlarla karşılaştık. Gerekli yardımı alarak düzelttik." (ÖA 31)

Öğretmen adaylarının açıklamalarından grupların süreç içinde genellikle teknik sorunlarla karşılaştıkları, bu problemleri yardım ve görüş alarak ya da denemeler yaparak çözdükleri belirlenmiştir.

Öğretmen adaylarının bir kısmı ise öykü yazımı aşamasında; öyküyü kurgulama, seviyeye uygun yazma, çizgi resim yapma, soyut kavramları somutlaştırma gibi engellerle karşılaştıklarını belirtmişlerdir. Öğretmen adaylarının çoğu karşılaştıkları bu problemlerin üstesinden, derslerde öğretim üyesi ve akranlarıyla tartışarak görüş alma ile matematik öğretmenleri ve öğrencilerle görüşmeler gerçekleştirerek, geldiğinin üzerinde durmuştur. Öğretmen adaylarının konuya ilişkin görüşlerine aşağıda yer verilmiştir.

"Grubumuzdaki arkadaşların hepsi öyle bir toplanmışız ki öykü yazmak için hayal gücü ve yaratıcılık sıfır, hiç yok. Ne yapacă̆ız, ne yazacağız? Daha önce hiç böyle bir şey yazmamışız. Çok düşündük başta, çok sorun yaşadık. En büyük hatamız başta yazamadığımız için anlatacağımız konuyu detaylı ve etkili bir şekilde nasıl anlatırız noktasına odaklanmaktan ziyade konu içindeki bilgileri art arda sıralamaya çalışmamız oldu. Bu yüzden ilk dijital öykümüzü yazarken çok zorlandık. Ama sonrasında diğer gruplara danıştık, tartıştık ve fikir aldık yaptıklarımız için. [...]"(ÖA 17)

"Dijital öykümüzde vereceğimiz konu çok soyuttu. Doğal olarak bu da bizi öykü yazarken zorladı. Ayrıca seviyeye göre yazmaya çalışmak da zordu. 'Basit mi oldu, çok zor mu oldu, anlamazlar mı?' diye düşündük hep. [...] Ama sınıftaki diğer arkadaşların çok faydası oldu süreç içinde bize. Sunum yaparken takıldığımız yerleri hep birlikte tartıştık, çözüm bulmaya çalıştık." (ÖA 53)

Ek olarak aynı grupta yer alan üç öğretmen adayı başlangıçta çeşitli fikirleri olduğunu, öykülerine ve öykülerindeki karakterlere karar vermekte zorlandıklarını, bu zorluğu da okullarda öğrenim gören sekizinci sınıf öğrencileri ile görüşmeler gerçekleştirerek aştıklarını belirtmişlerdir. Diğer katılımcılardan farklı olarak yedi öğretmen adayı ise grup çalışmasından kaynaklanan birlikte çalışma, işbölümündeki görevlerin yerine getirilmemesi, diğer 
arkadaşlarına bağımlı olma ve grup içinde eşit olmayan iş yükleri gibi problemler yaşadıklarını ifade etmişlerdir.

\section{3. Öğretmen Adaylarının Dijital Öykülemenin Matematik Öğretiminde Kullanımına ilişkin Görüşleri}

Öğretmen adaylarının dijital öykülemenin matematik öğretiminde kullanımına ilişkin düşünceleri incelendiğinde çoğunlukla dijital öykülemenin avantaj ve dezavantajlarının üzerinde durdukları görülmüştür. Öğretmen adaylarının dijital öykülemenin matematik öğretiminde kullanımına yönelik belirttikleri avantajlara ilişkin ortaya çıkan temalar ve bunlara ilişkin kodlar Tablo 3'te yer almaktadır.

Tablo 3

Dijital Öykülemenin Avantajlarına ilişskin Tema ve Kodlar

\begin{tabular}{clc}
\hline Temalar & \multicolumn{1}{c}{ Kodlar } & $\mathbf{f}^{*}$ \\
\hline \multirow{3}{*}{ Öğretime } & Öğrenmenin kolay ve kalıcı olmasını sağlaması & 38 \\
İlişkin & Sürece aktif katılımı sağlaması & 35 \\
Avantajlar & Başarıyı artırması & 27 \\
& Uygulamada zamanı ekonomik kullanmayı sağlaması & 8 \\
& Öğrenme ortamına çeşitlilik katması & 3 \\
\hline & Ilgi çekici olması & 43 \\
Duyuşsal & Eğlenerek öğrenmeyi sağlaması & 29 \\
Avantajlar & Derse güdülemede etkili olması & 29 \\
& Motivasyonu artırması & 11 \\
\hline \multirow{2}{*}{ Becerilere } & Yaratıcılığı geliştirmesi & 21 \\
ilişkin & Teknolojik yeterlikleri geliştirmesi & 19 \\
Avantajlar & Araştırma becerisini geliştirmesi & 15 \\
& Günlük yaşamla ilişkilendirme fırsatı vermesi & 13 \\
\hline
\end{tabular}

* : Bazı öğretmen adaylarının cevapları birden fazla kod altında yerleştirildiği için toplam frekans değeri $54^{\prime}$ ü aşabilir.

Tablo 3 incelendiğinde dijital öykülemenin öğretmen adayları tarafından üzerinde en fazla durulan avantajları arasında 'ilgi çekici olması, öğrenmenin kolay ve kalıcı olmasını sağlaması, sürece aktif katılımı sağlaması, derse güdülemede etkili olması, eğlenerek öğrenmeyi sağlaması ve başarıyı artırması' gelmektedir. Öğretmen adaylarının çoğunun dijital öykülemenin; kullanılan video, animasyon, ses gibi çoklu ortam öğelerinden dolayı etkili bir araç olduğunu belirtmeleri; bazı öğretmen adaylarının da matematiğin zor bir ders olduğunu düşünen öğrencilerin önyargılarının yıkılarak, matematik öğrenmenin kolay ve eğlenceli olduğunu düşünmelerini sağlayabileceğini ifade etmeleri dikkat çekmiştir.

Öğretmen adaylarının dijital öykülemenin dezavantajlarına ilişkin görüşlerinin analizinden ortaya çıkan kodların frekans değerleri Tablo 4'te yer almaktadır.

Tablo 4

Dijital Öykülemenin Dezavantajlarına İlişkin Tema ve Kodlar

\begin{tabular}{clc}
\hline Temalar & \multicolumn{1}{c}{ Kodlar } & $\mathbf{f}^{*}$ \\
\hline Öğreten & Öykü yazımının zor olması & 33 \\
Açısından & Hazırlanmasının zaman alıcı olması & 43 \\
\hline Öğrenen & Dikkat dağıtması & 11 \\
Açısından & Her öğrenen için uygun olmaması & 5 \\
\hline \multirow{2}{*}{ Öğretim } & Her kavram ya da kazanım için uygun olmaması & 21 \\
Açısından & Her zaman öğretimin her aşaması için uygun olmaması & 15 \\
& İyi planlanıp hazırlanmadığı durumlarda etkili öğretimin gerçekleşmemesi & 37 \\
\hline
\end{tabular}


* : Bazı öğretmen adaylarının cevapları birden fazla kod altında yerleştirildiği için toplam frekans değeri 54 ü aşabilir.

Tablo 4 incelendiğinde öğretmen adaylarının dijital öykülemenin dezavantajlarını öğreten, öğrenen ve öğretim kapsamında değerlendirdikleri görülmektedir. Katılımcıların dijital öykülemenin dezavantajlarına ilişkin görüşleri şu şekildedir:

"[...] Dijital öykülemeyi kullanmak için iyi bilmek gerekiyor, üzerine çok uğraşmak gerekiyor. Eğer iyi hazırlanmazsa öğrencilerin dikkatleri dağılır ve konuyu ögrrenemezler." (ÖA 28)

"Matematiksel bilgi ve becerilerin sadece dijital öyküleme ile kavratılmaya çalışılması kazanımın anlaşılması noktasında yeterli değildir. [...] Üstelik hep bu şekilde ders işlenirse artık öğrenciler sıkılırlar, farklı bir şey olmaz o artık. $O$ yüzden de dikkat çekmez." (ÖA 9)

"Bu yöntemin matematik konularının hepsinin anlatımında etkili olmayacağını düşünüyorum. Bazen öğretme-öğrenme süreci için, bazen de ölçme-değerlendirme süreci için uygun olabilir. Bu yöntem pekiştirme ya da konunun anlatımında destekleyici olurken bazı durumlarda konunun birebir öğretiminde yeterli olmayabilir." (ÖA 11)

\section{4. Öğretmen Adaylarının Öğretmenlik Yaşamlarında Dijital Öykülemeyi Kullanmaya ilişkin Görüşleri}

Öğretmen adaylarına göreve başladıklarında derslerinde dijital öykülemeyi kullanmayı tercih edip etmeyecekleri sorulduğunda, katılımcılar farklı durumlar belirterek tercih edebileceklerini ifade etmişlerdir. Öğretmen adaylarının dijital öykülemeyi tercih etme durumlarına ilişkin kodlar Tablo 5'te sunulmuştur.

Tablo 5

Ileride Dijital Öykülemeyi Tercih Etme Durumlarına Iliş̧in Tema ve Kodlar

\begin{tabular}{|c|c|c|}
\hline Tema & Kodlar & $f^{*}$ \\
\hline \multirow{4}{*}{ 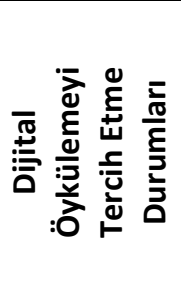 } & Uygun olabileceği düşünülen kazanımlarda tercih etme & 30 \\
\hline & $\begin{array}{l}\text { Öğrencilerin dikkatini çekerek kalıcı ve etkili öğrenmeye katkı } \\
\text { sağlayacağından tercih etme }\end{array}$ & 13 \\
\hline & $\begin{array}{l}\text { Çok zaman alıcı olması sebebiyle ancak hazır dijital öykülere erişebilmeleri } \\
\text { durumunda tercih etme }\end{array}$ & 15 \\
\hline & $\begin{array}{l}\text { Okulların gerekli donanıma sahip olması ve teknik desteğin sağlanması } \\
\text { durumunda tercih etme }\end{array}$ & 2 \\
\hline
\end{tabular}

* : Bazı öğretmen adaylarının cevapları birden fazla kod altında yerleştirildiği için toplam frekans değeri 54 'ü aşabilir.

Katılımcıların ileriki öğretim uygulamalarında dijital öykülemeyi kullanmaya yönelik düşünceleri aşağıda yer almaktadır.

"Bazı kazanımlarda tercih ederim. Zor anlaşılan kavramlara yönelik kullanırım özellikle. Ama her kavram için uygun olduğunu düşünmüyorum, özellikle matematikte. Kullanma nedenim de daha kalıcı öğrenmeyi sağlayacağından." (ÖA 7)

"ileride tercih ederim. Çünkü dijital öyküleme kalıcı ve etkili bir anlatım sunma imkânı sağlar ve sınıfta öğrencilerin dikkatini çekecek farklı bir şey kullanmış olurum."(ÖA 23) 
"Dijital öykülerin hazırlanması oldukça zaman alıyor. Fakat hazır dijital öyküleri ögrrencileri güdülemek ve dersi zevkli hale getirmek amacılla ara ara kullanabilirim. Her zaman tercih edeceğim bir yöntem değil." (ÖA 25)

"Açıkçası ben bunu hazırlamak için vakit harcamazdım. Elde olan hazır dijital öyküler varsa onları kullanırım. Yoksa da her konu için uğraşmam. [...]" (ÖA 38)

Öğretmen adaylarından ikisinin (ÖA29 ve ÖA52) diğerlerinden farklı olarak dijital öykülemeyi öğretim ortamlarında kullanılabilmeleri için öncelikle okulların gerekli donanıma sahip olması ve teknik desteğin sağlanması gerektiği üzerinde durmuş olması dikkat çeken bulgular arasındadır.

\section{5. Öğretmen Adaylarının Verilen Hizmet-Öncesi Eğitime İlişkin Görüşleri}

Öğretmen adaylarından son olarak, dijital öyküleme üzerine almış oldukları hizmetöncesi eğitimi değerlendirmeleri istenmiştir. Verilen eğitim ile ilgili görüşlerin verilerinin analizi sonucu Tablo 6'da belirlenen iki temaya ulaşımış ve ilişkili kodlar tabloda verilmiştir.

Tablo 6

Verilen Hizmet-Öncesi Eğitimin Değerlendirilmesine Illişkin Tema ve Kodlar

\begin{tabular}{|c|c|c|}
\hline Temalar & Kodlar & $f^{*}$ \\
\hline \multirow{4}{*}{ 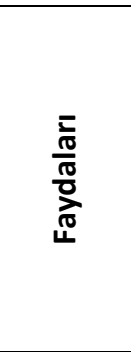 } & $\begin{array}{l}\text { Teorik bilgileri uygulamaya dönüştürülebilecek ortamların } \\
\text { sağlanması }\end{array}$ & 34 \\
\hline & $\begin{array}{l}\text { Araştırarak ve akranlar tarafından hazırlanan dijital öykülerden } \\
\text { yeni bilgilerin farklı bakış açılarıyla öğrenilmesine fırsat tanıması }\end{array}$ & 28 \\
\hline & $\begin{array}{l}\text { Büyük grup tartışmalarının etkin öğrenme ortamının oluşmasına } \\
\text { katkı sağlaması }\end{array}$ & 22 \\
\hline & $\begin{array}{l}\text { Gerçek sınıf ortamında gerçekleştirilen uygulamaların gelecek } \\
\text { uygulamaların nasıl gerçekleşebileceği konusunda fikir vermesi }\end{array}$ & 13 \\
\hline \multirow{2}{*}{ 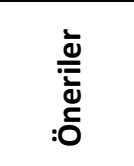 } & $\begin{array}{l}\text { Yeni ve çağa uygun yöntemlere yönelik verilen eğitimlerin } \\
\text { artırılması }\end{array}$ & 3 \\
\hline & $\begin{array}{l}\text { Daha yetkin olabilmek için sınıf ortamında uygulama aşamasında } \\
\text { uygulayıcı olarak dâhil olunması }\end{array}$ & 3 \\
\hline
\end{tabular}

* : Bazı öğretmen adaylarının cevapları birden fazla kod altında yerleştirildiği için toplam frekans değeri 54 'ü aşabilir.

Öğretmen adaylarının verilen hizmet-öncesi eğitime yönelik değerlendirmelerini yaparken bu eğitimin faydalarına değindikleri ve önerilerde bulundukları Tablo 6'dan anlaşılmaktadır. 34 öğretmen adayı öğrenilen teorik bilgilerin uygulamaya dönüştürülebileceği ortamların sağlanmasının etkili olduğunu, 28 öğretmen adayı kendilerinin araştırarak öğrenmelerine ve diğer grupların hazırladığı dijital öykülerden yeni bilgileri farklı bakış açılarıyla öğrenmelerine fırsat tanıdığını, 22 öğretmen adayı sunumlar ile birlikte yürütülen büyük grup tartışmalarının etkin öğrenme ortamının oluşmasına katkı sağladığı düşüncesinde olduğunu belirtmiştir. 13 öğretmen adayı ise gerçek sınıf ortamında gerçekleştirilen dijital öyküleme uygulamalarının gözlenmesinin ilgili konuda karşılaşılabilecek problemler ve bu problemlere ilişkin çözüm önerileri hakkında bilgi vererek, daha etkili uygulamaların nasıl gerçekleşebileceği konusunda fikir verdiğini ifade etmiştir. Ek olarak 3 öğretmen adayı özellikle dijital öyküleme gibi günümüz koşullarında yeni ve çağa uygun yöntemlere yönelik verilen eğitimlerin artırılması gerektiğini belirtmiştir. Ayrıca bazı katılımcılar (3 öğretmen adayı) diğerlerinden farklı olarak; geliştirilen dijital öykülerin sınıf ortamında uygulama aşamasında sürece gözlemci olarak değil de, sürece uygulayıcı olarak katıldıkları durumda daha yetkin olabileceklerini belirtmişlerdir. 


\section{SONUÇ, TARTIŞMA VE ÖNERILER}

Günümüzde artık öğretmenlerin hem teknolojiyi iyi derecede kullanma becerileri sergileyebilmeleri hem de bu teknolojileri öğrenme-öğretme süreçlerinde verimli olarak kullanabilmeleri gereklidir (Gündüz ve Odabaşı, 2004; Öksüz, Ak ve Uça, 2009). Eğitimde teknoloji kullanımı özellikle zor ve karmaşık olan matematik öğrenme sürecinde merak uyandırmada etkilidir (Incikabi, 2015).

Matematik öğretiminde öyküleme; öğrencilerin aktif olmalarını sağlayan, problem çözme becerilerini geliştiren (Albano \& Pierri, 2014), zor kavramları anlamalarını derinleştirmelerini, matematiksel fikirleri tartışmalarını, yazmalarını, okumalarını ve dinlemelerini sağlayan eğlenceli ve çok yönlü bir araçtır (Goral ve Gnadinger, 2006). Dijital öykülemenin yüksek düzeyde teknoloji entegrasyonu açısından matematik öğretiminde etkili bir öğrenme aracı olarak kullanılabileceği düşünülerek gerçekleştirilen çalışmada öncelikle öğretmen adaylarının dijital öykülerini oluştururken karşılaştıkları problemlerin neler olduğu ve bu problemleri nasıl çözdüklerine ilişkin görüşleri alınmıştır. Çalışmanın sonunda öğretmen adaylarının büyük çoğunluğunun teknik sorunlarla karşılaştıkları ve senaryo oluşturma sürecinde zorlandıkları ortaya çıkmıştır. Kildan ve Incikabi (2013), Karakoyun (2014), İnan (2015) ile Karatay, Bozkurt ve Hava'nın (2016) çalışmalarında da öğretmen adayları benzer sorunlarla karşılaşmışlardır. Jakes ve Brennan (2005) sesin kaydedilmesinin (seslendirme) dijital öykülerin hazırlanmasındaki en zor bileşen olduğunu belirtmiştir. Bu çalışmada da öğretmen adayları dijital öykülerini oluştururken özellikle sesin kaydedilmesi sürecinde zorlandıklarının üzerinde durmuşlardır. Benzer olarak İnan'ın (2015) çalışmasında öğretmen adaylarının video oluşturma gibi dijital okuryazarlık gerektiren aşamalarda yardıma ihtiyaçları olduğu gözlemlenmiştir. Jakes ve Brennan (2005) öykü panolarının hazırlanması aşamasını birçok öğrencinin sevmediğini, süreçte zorluk olarak gördüğünü ve öğretmenlerin çoğunun önemli olduğu halde bu adımı geçtiğinden söz etmiştir. Karakoyun (2014) çalışmasında da katılımcılar hikâye panosu oluşturmayı beğenmediklerini ve gereksiz gördüklerini belirtmişlerdir. Ancak bu çalışmada öğretmen adaylarının bu basamağı bir engel olarak belirtmiş olmamaları dikkat çekmiştir.

Öğretmen adaylarının büyük çoğunluğunun dijital öykülemenin öğretim ortamlarında kullanımının ilgi çekici, öğrenimi kolay ve kalıcı kılıcı, sürece etkin katılımı sağlayıcı, derse güdüleyici ve eğlenerek öğrenmeyi sağlayıcı etkisi olduğunu düşündükleri belirlenmiştir. Benzer olarak Karakoyun (2014) ve İnan (2015) çalışmalarında öğretmen adaylarının dijital öykülemeyi ilgi çekici ve eğlenceli bulduklarından; Yüksel, Robin ve McNeil (2011) ile Xu, Park ve Baek (2011) dijital öykülemenin kolay ve kalıcı öğrenmeyi desteklediğinden; Van Gils (2005) ilgi çekici olduğundan; Karakoyun (2014), Robin (2006) ve Xu, Park ve Baek (2011) ise aktif öğrenmeyi sağladığından bahsetmişlerdir. Karataş, Bozkurt ve Hava'nın (2016) tarih öğretmeni adayları ile gerçekleştirdikleri çalışmanın sonucunda da dijital öykülemenin ilgi çekici olması, öğrenmeyi kolaylaştırması, kalıcı ve aktif öğrenmeyi sağlaması gibi faydalarının olduğu ortaya çıkmıştır.

Çalışmada öğretmen adayları, sınıf içinde dijital öyküleme uygulamalarının başarı ve motivasyona da olumlu etkileri olduğuna değinmişlerdir. Alanyazın incelendiğinde bu sonucunu destekleyen birçok çalışmanın olduğu görülmektedir. Long (2011) öğretmen adayları ile yaptığı çalışmasının sonucunda katılımcıların dijital öyküleme sürecini motive edici ve değerli bir deneyim olarak bulduklarını tespit etmiştir. Yang ve Wu (2012) çalışmalarının sonunda dijital öykülemenin öğrencilerin başarı ve motivasyonları üzerinde olumlu etkisinin olmasının yanı sıra öğrenmeyi kolaylaştırdığı, keşfetme ve öğrenme isteklerini de artırdığı sonucuna ulaşmıştır. Hung, Hwang ve Huang'ın (2012) gerçekleştirdikleri deneysel çalışmanın sonunda dijital öyküleme ile öğrenim gören öğrencilerin öğrenme motivasyonlarının ve başarılarııın arttığı 
belirlenmiştir. Göçen (2014) de dijital öykülemeye dayalı öğrenimin öğrencilerin akademik başarıları ile öğrenme ve ders çalışma stratejilerine etkisini incelediği ve deneysel olarak desenlediği tez çalışmasında, dijital öykülemenin akademik başarıyı artırma ile öğrenme ve ders çalışma stratejileri kullanımı üzerinde Powerpoint sunum destekli öğretime göre daha etkili olduğu sonucuna ulaşmıştır. Karataş, Bozkurt ve Hava (2016) ise çalışmalarında, öğretmen adaylarının dijital öykülemenin öğrencilerin motivasyonunu artırdığını düşündüklerini belirlemişlerdir.

Çalışmada bazı öğretmen adayları da öğretim ortamında dijital öykülemenin kullanılması ile kazanımların günlük yaşamla daha kolay ilişkilendirilebileceğini, öğrenenlerin yaratıcı düşünme ve araştırma becerileri ile teknolojik yeterliklerinin gelişeceğini düşündüklerini belirtmişlerdir. Nitekim alanyazın incelendiğinde de dijital öykülemenin öğretim etkinliklerini gerçek yaşam durumları ile bütünleştirmeyi sağladığının (Di Blas, Garzotto, Paolini ve Sabiescu, 2009; Kocaman-Karaoğlu, 2015; McLellan, 2006; Woodhouse, 2008) öğrencilerin araştırma (Ohler, 2006; Robin, 2006) ve yaratıcı düşünme becerilerini (Duman ve Göcen, 2015; Duveskog, Tedre, Sedano ve Sutinen, 2012; Karataş, Bozkurt ve Hava, 2016; Woodhouse, 2008), teknolojik yeterliklerini (Jakes ve Brennan, 2005; Kocaman-Karaoğlu, 2015; Robin, 2006) geliştirdiğinin üzerinde durulduğu görülmektedir. İnan'ın (2015) öğretmen adayları ile gerçekleştirdiği çalışmasında da katıımcıların üzerinde durdukları hususlardan biri de dijital öykülemenin matematik bilgilerinin günlük yaşam ile ilişkilendirmesini kolaylaştırdığı olmuştur.

Van Gils (2005) dijital öykülemenin geleneksel yöntemlere göre daha fazla çeşitlilik sunacağını belirtmekte ve bu hususu dijital öykülemenin en açık avantajlarından biri olarak görmektedir. Dijital öykülemenin üretme gücünden dolayı öyküler çeşitlilik göstermekte, bu durum da öğrenmeyi monotonluktan ve sıkıcı olmaktan kurtarmaktadır. Bu çalışmada da bazı öğretmen adayları dijital öykülemenin sınıftaki öğrenme ortamına çeşitlilik kattığından söz etmişlerdir. Öğretmen adaylarının bir kısmının ise dijital öykülerin uygulama aşamasında zamanı ekonomik kullanmayı sağladığı düşüncesinde oldukları belirlenmiştir. Karataş, Bozkurt ve Hava'nın (2016) çalışmasından elde edilen dijital öykülerin öğretim ortamında kullanılmasının konuların özet şeklinde verilmesi açısından faydalı olabileceği sonucu, çalışmanın bu sonucunu destekler niteliktedir. Ayrıca Duveskog, Tedre, Sedano ve Sutinen (2012) çalışmalarında dijital öykülemenin materyal olarak ve sunumun tekrar kullanılması durumunda öğretimde zaman kazandırabileceği sonucu da çalışmanın ilgili sonucuna paralel niteliktedir.

Dijital öykülemenin olumsuzlukları arasında öğretmen adayları tarafından en çok vurgulanan hususlar; hazırlanmasının zaman alıcı olması, iyi planlanıp hazırlanmadığı durumlarda etkili öğretimin gerçekleşmemesi ve öykü yazma sürecinin zor olması olmuştur. Robin (2006) dijital öykülemenin öğrenenler ve öğreticiler için birtakım zorlukları barındırdığını ifade ederek; etkili ve iyi hazırlanmamış dijital öykülerin amaca ulaşmayı engellediği ve de dijital öykülemenin çok zaman alabileceği üzerinde durmuştur. Benzer olarak Woodhouse (2008) de dijital öykülerin hazırlanmasının çok zaman almasını dezavantaj olarak değerlendirmiştir. Duveskog, Tedre, Sedano ve Sutinen (2012) ise çalışmalarında dezavantajlar arasında yeni dijital araçları öğrenmek için harcanan zaman ile kayıt ve düzenleme için gerekli olan zamanı göstermişlerdir. İnan'ın (2015) çalışmasında da öğretmen adaylarının dijital öykülemeyi zaman açısından ekonomik olarak bulmadıkları belirlenmiştir.

Öğretmen adaylarının bir kısmının ise dijital öykülemenin her konu için ve öğretimin her aşaması için uygun olmadığını ve de etkili hazırlanmadığı ya da sürekli kullanıldığı durumda öğrencilerin dikkatlerini dağıtabileceğini düşündükleri ortaya çıkmıştır. Benzer olarak Yüksel, Robin ve McNeil (2011) çalışmalarında dijital öykülemenin öğretim ortamlarında sürekli olarak kullanılmasının dikkat dağıtıcı olabileceğini ve öğretmenin süreci etkili bir şekilde planlamasının 
bu problemi çözebileceğini belirtmişlerdir. Woodhouse (2008) öykülemelerin görselleştirme becerilerini gerektirdiğini, dolayısıyla da her bireyin öğrenmesi için uygun olmayacağını belirtmiştir. Bu çalışmada da öğretmen adaylarının bazıları dijital öykülemenin her öğrenen için uygun bir yöntem olmadığı görüşündedir.

Araştırmaya katılan öğretmen adaylarının mesleki yaşamlarında öğretimleri esnasında dijital öykülemeyi kullanmayı istedikleri belirlenmiştir. Bu sonuç Doering, Beach ve O'Brien (2007), Sadik (2008) ile Karataş, Bozkurt ve Hava'nın (2016) çalışmalarının öğretmen adayları ve öğretmenlerin öğretim ortamlarında dijital öykülemeyi kullanma konusunda istekli olma sonuçları ile benzerlik göstermektedir. İnan'ın (2015) çalışmasında ise öğretmen adaylarının dijital öykülemeyi sevdikleri ve öğretimlerinde kullanacaklarını belirttikleri ortaya çıkmıştır. Karakoyun'un (2014) çalışmasında ise öğretmen adaylarının tamamının gelecekte eğitim hayatlarında dijital öykülemeyi kullanmayı düşündükleri belirlenmiştir.

Katılımcıların bazıları öğretim ortamlarında dijital öykülemenin kullanılabilmesi için okulların gerekli donanıma sahip olması ve teknik desteğin sağlanması koşullarının gerçekleşmesi gerektiğini düşünmektedir. Ertmer (1999) öğretim sürecinde teknoloji kullanılırken bazı engellerle karşılaşıldığını belirtmiş ve teknoloji entegrasyonuna engel olan nedenleri iki grupta( i.araç-gereç, eğitim ve teknik destek yetersizliği, ii. öğretmen tutumu ve zayıf öğretmen-öğrenci ilişkisi) sınıflandırmıştır. Ayrıca alanyazın incelendiğinde okullarda yeterli teknik desteğin sağlanması durumunda öğretmenlerin teknolojiyi öğrenme-öğretme sürecinde kullanabilecekleri görülmektedir (Assan ve Thomas, 2012; Çakır ve Yıldırım, 2009; Yılmaz, 2011).

Öğretmen adaylarından aldıkları eğitimi değerlendirmeleri istendiğinde verilen eğitimin faydalarına değindikleri, bazı öğretmen adaylarının da özellikle dijital öyküleme gibi günümüz koşullarında işe yarayacak olan yöntemlere yönelik verilen eğitimlerin artırılması ve uygulayıcı olarak sürece dâhil olabilme konusunda öneride bulundukları ortaya çıkmıştır. Elde edilen sonuçtan farklı olarak Büyükgöze Kavas ve Bugay (2009) öğretmen adaylarının hizmet-öncesi eğitimleri sırasında karşılaştıkları eksikliklere ve bu eksikliklere yönelik çözüm önerilerine ilişkin görüşlerini belirlemek amacıyla gerçekleştirdiği çalışmalarında; öğretmen eğitimi programında verilen eğitimin mezuniyet sonrası için yetersiz görüldüğü, yapılan uygulamaların etkili öğretmenlik becerilerini kazandırma açısından yetersiz kaldığı ve teorik bilginin çok fazla olmasının öğrenciler tarafından hizmet-öncesi eğitimde görülen eksikliklerin başında yer aldığı sonucuna ulaşmıştır. Çözüm önerisi olarak da derslerde uygulamaların iyileştirilmesinin gerektiğini, öğrenci merkezli eğitimin gerçekleştirilmesinin gerektiğini ve ders içeriklerinin günümüz koşullarıyla uyuşmasının sağlanması gerektiğini belirtmişlerdir. Ayrıca Arslan ve Özpınar'ın (2008) çalışmasında da öğretmen adayları, yeni teknolojilerin derslerde kullanımı konusunda kendilerini yeterli görmelerine rağmen; gerçek sınıf ortamında yeteri düzeyde uygulama imkânı bulamadıklarından öğretmenlik sürecinde uygulamayla ilgili endişeleri olduğunu ifade etmişlerdir.

Akran değerlendirmesi, grup tartışmalarının teşviki, öğretmenin gözlemleri ve geribildirimde bulunması etkili dijital öyküleme sürecinde önemlidir (Kearney, 2011). Bu çalışmada da öğretmen adaylarının sunumlar ile birlikte yürütülen büyük grup tartışmalarının etkili öğrenme ortamlarının oluşmasına katkı sağladığını düşündükleri ortaya çıkmıştır.

Alanyazında birçok araştırmacının eğitim ortamlarında yer alabilecek etkili ve güçlü bir araç olarak gösterdiği dijital öykülemenin daha etkin uygulanabilmesi için öğretmen adaylarının fakülteden mezun olmadan, mevcut öğretmenlerin de hizmet-içi eğitimlerde bu konuda nitelikli bir şekilde eğitim alarak yaygınlaştırılması ve dijital öykülemeyi öğretim süreçlerinde kullanmaları sağlanabilir. Bu araştırma matematik öğretmenliği programında öğrenim 
görmekte olan öğrenciler ile gerçekleştirilmiştir. Sınıf öğretmenliği programında bulunan öğrencilere de benzer eğitim verilerek farklı seviyelerdeki matematik kazanımlarına yönelik havuz oluşturulabilir ve öğretmen adaylarının oluşturdukları dijital öykülerin öğretim materyali olarak paylaşılması sağlanabilir. Bu araştırmada dijital öyküler grup çalışması yoluyla oluşturulmuştur, ancak bazı öğretmen adayları bunu bir engel olarak görmüştür. Dolayısıyla katılımcılara bireysel olarak dijital öykü oluşturma fırsatı da tanınabilir.

\section{KAYNAKLAR}

Albano, G. ve Pierri, A. (2014). Digital storytelling for improving mathematical literacy. In S. Carreira, N. Amado, K. Jones ve H. Jacinto (Eds), Proceedings of the Problem@Web international conference: technology, creativity and affect in mathematical problem solving (pp. 23-34). Faro: Universidade do Algarve.

Arslan, S. ve Özpınar, í. (2008). Öğretmen nitelikleri: İlköğretim programlarının beklentileri ve eğitim fakültelerinin kazandırdıkları. Necatibey Eğitim Fakültesi Elektronik Fen ve Matematik Eğitimi Dergisi, 2(1), 38-63.

Assan, T. ve Thomas, R. (2012). Information and communication technology Integration into teaching and learning: Opportunities and challenges for commerce educators in South Africa. International Journal of Education and Development Using Information and Communication Technology, 8(2), 4-16.

Atıcı, M. (2001). Öğretmen yetkinliği. Kuram ve Uygulamada Eğitim Yönetimi, 28, 483-499.

Baki, A. (2000). Preparing student teachers to use computers in mathematics classroom through a long-term preservice course in Turkey. Journal of Information Technology for Teacher Education, 9(3), 343-362.

Baki, A., Yalçınkaya, H. A., Özpınar, ì. ve Çalık Uzun, S. (2009). Comparing views of primary school mathematics teachers and prospective mathematics teachers about instructional technologies. Turkish Journal of Computer and Mathematics Education (TURCOMAT), 1(1), 65-83.

Balakrishnan, C. (2008). Teaching secondary school mathematics through storytelling (Master dissertation, Simon Fraser University).

Barrett, H. (2009). How to create simple digital stories. electronicportfolios.com/digistory/howto.html adresinden 12.02.2017 tarihinde edinilmiştir.

Büyükgöze Kavas, A. ve Bugay, A. (2009). Öğretmen adaylarının hizmet öncesi eğitimlerinde gördükleri eksiklikler ve çözüm önerileri. Pamukkale Üniversitesi Eğitim Fakültesi Dergisi, 25(25), 13-21.

Cakir, R. ve Yildirim, S. (2009). What do computer teachers think about the factors affecting technology integration in schools. Illkögretim Online, 8(3), 952-964.

Casey, B. (2004). Mathematics problem-solving adventures: A language-arts-based supplementary series for early childhood that focuses on spatial sense. In D. H. Clements, J. Sarama \& A.-M. DiBiase (Eds.), Engaging young children in mathematics: Standards for early childhood mathematics education (pp. 377-389). Mahwah, NJ: Lawrence Erlbaum Associates, Publishers.

Casey, B., Erkut, S., Ceder, I. ve Young, J. M. (2008). Use of a storytelling context to improve girls' and boys' geometry skills in kindergarten. Journal of Applied Developmental Psychology, 29(1), 29-48. 
Casey, B., Kersh, J. E. ve Young, J. M. (2004). Storytelling sagas: An effective medium for teaching early childhood mathematics. Early Childhood Research Quarterly, 19(1), 167172.

Condy, J., Chigona, A., Gachago, D. ve Ivala, E. (2012). Pre-service students' perceptions and experiences of digital storytelling in diverse classrooms. TOJET: The Turkish Online Journal of Educational Technology, 11(3), 278-285.

Cuban, L., Kirkpatrick, H. ve Peck, C. (2001). High access and low use of technologies in high school classrooms: Explaining an apparent paradox. American Educational Research Journal, 38(4), 813-834.

Demir, S. ve Bozkurt, A. (2011). İlköğretim matematik öğretmenlerinin teknoloji entegrasyonundaki öğretmen yeterliklerine ilişkin görüşleri. Ilköğretim Online, 10(3), 850-860.

Di Blas, N., Garzotto, F., Paolini, P. ve Sabiescu, A. (2009, December). Digital storytelling as a whole-class learning activity: Lessons from a three-years project. In Joint International Conference on Interactive Digital Storytelling (pp. 14-25). Springer Berlin Heidelberg.

Doering, A., Beach, R. ve O'Brien, D. (2007). Infusing multimodal tools and digital literacies into an English education program. English Education, 40(1), 41-60.

Dogan, B. ve Robin, B. (2008). Implementation of digital storytelling in the classroom by teacherstrained in a digital storytelling workshop. K. McFerrin v.d. (Ed.), Proceedings of Society for Information Technology \& Teacher Education International Conference (s. 902-907). Chesapeake, VA: AACE.

Duman, B. ve Göcen, G. (2015). The effect of the digital storytelling method on pre-service teachers' creative writing skills. ANTHROPOLOGIST, 20(1-2), 215-222.

Duveskog, M., Tedre, M., Sedano, C. I. ve Sutinen, E. (2012). Life planning by digital storytelling in a primary school in Rural Tanzania. Educational Technology \& Society, 15(4), 225237.

Ertmer, P. A. (1999). Addressing first-and second-order barriers to change: Strategies for technology integration. Educational technology research and development, 47(4), 4761.

Goral, M. B. ve Gnadinger, C. M. (2006). Using storytelling to teach mathematics concepts. Australian Primary Mathematics Classroom, 11(1), 4.

Gordon, C. (2011). Digital storytelling in the classroom: Three case studies. (Unpublished doctoral dissertation). Arizona State University. Retrieved from ProQuest Digital Dissertations. (UMI 3487362)

Göçen, G. (2014). Dijital öyküleme yönteminin öğrencilerin akademik başarı ile öğrenme ve ders çalışma stratejilerine etkisi. Yayımlanmamış Yüksek Lisans Tezi, Muğla Sıtkı Koçman Üniversitesi, Eğitim Bilimleri Enstitüsü, Muğla.

Gündüz, Ş. ve Odabaşı, F. (2004). Bilgi çağında öğretmen adaylarının eğitiminde öğretim teknolojileri ve materyal geliştirme dersinin önemi. The Turkish Online Journal of Educational Technology, 3(1), 43-49.

Hardy, J. V. (1998). Teacher attitudes toward and knowledge of computer technology. Computers in the Schools. Vol. 14 (3/4), 119-136. 
Heo, M. (2009). Digital storytelling: An empirical study of the impact of digital storytelling on pre-service teachers' self-efficacy and dispositions towards educational technology. Journal of Educational Multimedia and Hypermedia, 18(4), 405.

Hung, C. M., Hwang, G. J. ve Huang, I. (2012). A Project-based digital storytelling approach for improving students' learning motivation, problem-solving competence and learning achievement. Educational Technology \& Society, 15(4), 368-379.

Incikabi, L. (2015). Teaching history of mathematics through digital stories: A technology integration model. In J. Keengwe (Eds.), Handbook of research on educational technology integration and active learning (pp.162-176.). Hersley, PA: IGI Global.

Incikabi, L. ve Kildan, A. O. (2013). An analysis of early childhood teacher candidates' digital stories for mathematics teaching. International Journal of Academic Research, 5(2), 7781.

Istenic Starčič, A., Cotic, M., Solomonides, I. ve Volk, M. (2016). Engaging preservice primary and preprimary school teachers in digital storytelling for the teaching and learning of mathematics. British Journal of Educational Technology, 47(1), 29-50.

Inan, C. (2015). A digital storytelling study project on mathematics course with preschool preservice teachers. Educational Research and Reviews, 10(10), 1476-1479.

Jakes, D. S. ve Brennan, J. (2005). Capturing stories, capturing lives: An introduction to digital storytelling. www.jakesonline.org/dstory_ice.pdf adresinden 01.03.2017 tarihinde edinilmiştir.

Karakoyun, F. (2014). Çevrimiçi ortamda oluşturulan dijital öyküleme etkinliklerine ilişkin ögrretmen adayları ve ilköğretim öğrencilerinin görüşlerinin incelenmesi. Yayımlanmamış Doktora Tezi, Anadolu Üniversitesi, Eğitim Bilimleri Enstitüsü, Eskişehir.

Karataş, S., Bozkurt, Ş. B. ve Hava, K. (2016). The perspective of history pre-service teachers' towards the use of digital storytelling in educational environments. Journal of Human Sciences, 13(1), 500-509.

Kearney, M. (2011). A learning design for student-generated digital storytelling. Learning, Media and Technology, 36(2), 169-188.

Kildan, A. O. ve Incikabi, L. (2015). Effects on the technological pedagogical content knowledge of early childhood teacher candidates using digital storytelling to teach mathematics. Education 3-13, 43(3), 238-248.

Kocaman-Karaoğlu, A. (2015). Öğretim sürecinde hikâye anlatmanın teknolojiyle değişen doğası: Dijital hikâye anlatımı. Eğitim Teknolojisi Kuram ve Uygulama, 5(2), 89-106.

Lederman, N. G. ve Niess, M. L. (2000). Technology for technology's sake or for the improvement of teaching and learning?. School Science and Mathematics, 100(7), 345348.

Long, B. (2011, February). Digital storytelling and meaning making: Critical reflection, creativity and Technology in pre-service teacher education. In Proceedings of the Digital storytelling conference (pp. 1-27).

McLellan, H. (2006). Digital storytelling in higher education. Journal of Computing in Higher Education, 19(1), 65-79. 
(2008). Matematik öğretmeni

özel

alan yeterlikleri. http://otmg.meb.gov.tr/alanmatematik.html adresinden 03.02.2017 tarihinde edinilmiştir.

MEB (2013). Ortaokul matematik dersi 5-8. sınıflar öğretim programı. Ankara: MEB Talim Terbiye Başkanlığı Yayınları.

Miles, M. ve Huberman, M. (1994). Qualitative data analysis (Second Edition). Beverly Hills, CA: Sage

Mistretta, R. M. (2005). Integrating technology into the mathematics classroom: The role of teacher preparation programs. Mathematics Educator, 15(1), 18-24.

Ohler, J. (2006). The world of digital storytelling. Educational Leadership, 63(4), 44-47.

Oral, B. (2004). Öğretmen adaylarının internet kullanma durumları. XIII. Ulusal Eğitim Bilimleri Kurultayı. İnönü Üniversitesi, Eğitim Fakültesi. Malatya.

Öksüz, C., Ak, Ş. ve Uça, S. (2009). İlköğretim matematik öğretiminde teknoloji kullanımına ilişkin algı ölçeği. Yüzüncü Yıl Üniversitesi, Eğitim Fakültesi Dergisi. Cilt:V1, Sayı: I, 270287.

Patton, M. Q. (2002): Qualitative Research and Evaluation Methods (3rd Edition). Thousand Oaks, CA: Sage.

Robin, B. R. (2006). The educational uses of digital storytelling. In C. Crawford vd. (Ed.), Proceedings of Society for Information Technology \& Teacher Education International Conference, (s. 709-716). Chesapeake, VA: AACE.

Robin, B. R. (2008). Digital storytelling: A powerful technology tool for the 21st century classroom. Theory Into Practice, 47, 220-228.

Robin, B. R. (2014). The effective uses of digital storytelling as a teaching and learning tool. James F. , Shirley B. H. ve Diane L. (Ed.) Handbook of research on teaching literacy through the communicative and visual arts: Volume II içinde (s.429-440). New York: MacMillan.

Sadik, A. (2008). Digital storytelling: A meaningful technology-integrated approach for engaged student learning. Educational Technology Research and Development, 56, 487-506.

Schiro, M. S. ve Lawson, D. (2004). Oral storytelling and teaching mathematics: Pedagogical and multicultural perspectives. SAGE publications.

Smeda, N., Dakich, E. ve Sharda, N. (2014). The effectiveness of digital storytelling in the classrooms: A comprehensive study. Smart Learning Environments, 1(1), 6.

Sancar Tokmak, H. ve Incikabi, L. (2013). Integration of the computer games into early childhood education pre-service teachers' mathematics teaching. Jared, K. (Ed.) Research perspectives and best practices in educational technology integration içinde (pp. 178-196). PA: IGI Global.

Van Gils, F. (2005, June). Potential applications of digital storytelling in education. In 3rd Twente Student Conference on IT (Vol. 7). University of Twente, Faculty of Electrical Engineering, Mathematics and Computer Science Enschede.

Woodhouse, J. (2008, June). Story-telling: A telling approach in healthcare education. Paper presented at the Narrative Practitioner Conference, Wrexham, UK. 
Xu, Y., Park, H. ve Baek, Y. (2011). A new approach toward digital storytelling: An activity focused on writing self-efficacy in a virtual learning environment. Educational Technology \& Society, 14(4), 181-191.

Yang, Y.T.C. ve Wu, W.C.I. (2012). Digital storytelling for enhancing student academic achievement, critical thinking, and learning motivation. A year - long experimental study. Computers \& Education, 59(2), 339- 352.

Yıldııım, A. ve Şimşek, H. (2006). Sosyal bilimlerde nitel araştırma yöntemleri (6. Baskı). Ankara: Seçkin Yayıncılık.

Yilmaz, N. P. (2011). Evaluation of the technology integration process in the Turkish education system. Contemporary Educational Technology, 2(1), 37-54.

Yin, R. K. (1994). Case study research design and methods (Second Edition). London: New Delhi.

Yuksel, P., Robin, B. ve McNeil, S. (2011). Educational uses of digital storytelling all around the world. M. Koehler ve P. Mishra (Ed.), Proceedings of Society for Information Technology \& Teacher Education International Conference (s. 1264-1271). Chesapeake, VA: AACE. 


\section{SUMMARY}

Achieving the change and improvement in education depends on several factors. One of the most important of those factors is teachers. Teachers first need to accept the change and be aware of the developments especially in technology so they can achieve changes in educational institutions. Yet, it is seen in the literature that preservice teachers graduate before having the sufficient knowledge and skills about technological integration. In this scope, it is thought that digital stories can be utilized as effective learning instruments in instructional environments especially for technological integration. Based on these considerations, the purpose of this study is to examine preservice teachers' competence levels of digital storytelling and opinions on the process of preservice education with components through which they learn digital storytelling, develop digital stories and observe how teachers implement the stories they develop and discuss the effectiveness of those activities.

Participants of this study which used the case study method within the scope of qualitative approach were 54 preservice teachers who are attending the third year of the mathematics education department in the Faculty of Education at a state university. The data of the research were collected with written interview forms.

First, preservice teachers' opinions on what were the problems they encountered while preparing digital storytelling activities and how they overcome those problems were taken within the scope of the research. It was revealed that majority of the preservice teachers had technical problems and experienced difficulties in the process of creating a scenario. Majority of the preservice teachers reported that they think using digital storytelling in instructional environments is interesting and makes learning easy and permanent and provide efficient participant in the process, motivates students for lesson and enable them to learn by having fun. In this study, the preservice teachers addressed that these activities had positive impacts on achievement and motivation. The preservice teachers think that learner achievements and motivations would be increased using the digital storytelling in the classroom environment. Some of the preservice teachers in the study stated that attainments would be associated with daily life more easily and creative thinking and research skills and technological competences of learners would improve using digital storytelling in an instructional environment.

Van Gils (2005) argues one of the most obvious advantages of digital storytelling is that provides much diversity than traditional methods. Stories diversify due to the productive power of digital storytelling, which keeps learning from being monotonous and boring. In this study, some of the participants mentioned that digital storytelling increased the diversity in the learning environment of the classroom and offered learning by having fun. Part of the preservice teachers thought that it enabled them to use time economically in the practical stage. Disadvantages of digital storytelling which were emphasized by the participants the most included it takes time to prepare the activities and effective instruction is not achieved when it is not well-planned and well-prepared.

It was also found that most of the participant preservice teachers want to use digital storytelling when they start teaching in future. Some of the participants think that the conditions of schools having the necessary equipment and providing the technical support need to be met so that digital storytelling can be used in instructional environments.

When the preservice teachers were asked about the education they receive, most of them stated that offering environments in which the learned theoretical information can be put into practice and observing the activities performed in real classroom settings suggests how more effective activities can be performed by offering possible hindrances and conveniences about digital storytelling and that the in-service education they had received was effective. Some of the preservice teachers think that educations for the methods such as digital storytelling which would be of use under today's circumstances should be provided more frequently.

For the digital storytelling which is considered an effective and powerful instrument in educational environments by several researchers in the literature to be applied more efficiently, preservice teachers before graduating from university and current teachers in in-service educations can be trained to make digital storytelling used more commonly and to enable them to use it in instructional processes. This research was conducted with the students studying in the elementary mathematics 
education program. By providing the students studying in the elementary education program with a similar education, a library can be created for mathematical attainments on different levels in the virtual environment and it can be ensured that preservice teachers share their own digital stories as an instructional material. Digital stories in this research were created in group works; however, some of the preservice teachers found this to be an obstacle. Opportunity to create digital stories individually can be accordingly offered to the participants.

In consideration of these results, it is thought that this study would provide preservice teachers with the information on the hindrances and conveniences of using digital storytelling in instruction and which points should be considered in future studies on the learning environment. 